\title{
Analisis Distribusi Temperatur Koefesien Perpindahan Panas pada Sistem Pendingin (Simulasi) Menggunakan Porous Media dengan Variasi Porositas
}

\section{Analysis of Temperature Distribution of Heat Transfer Coefficient in Cooling System (Simulation) Using Porous Media with Porosity Variation}

\author{
Ahmad Hamim Su'udy ${ }^{1}$, Eko Siswanto ${ }^{2}$, Rudy Soenoko ${ }^{2}$ \\ ${ }^{1}$ Program Magister Teknik Mesin, Fakultas Teknik Universitas Brawijaya' Malang, Indonesia \\ 2Jurusan Teknik Mesin, Fakultas Teknik Universitas Brawijaya' Malang, Indonesia
}

\begin{abstract}
Abstrak
Mesin pembakaran dalam adalah mesin yang cukup tua dan saat ini memiliki banyak energi alternatif yang ternyata belum mampu untuk menggeser peran dari mesin pembakaran dalam, untuk sistem pendingin pada mesin pembakaran dalam sangat mempengaruhi performa dan apabila tidak ditangani dengan baik akan menyebabkan sesuatu yang fatal, yaitu saat mesin terlalu panas dapat menyebabkan over heating dan mesin tidak dapat bekerja lagi. Untuk sistem Pendinginan selama ini menggunakan sirip dan radiator. Penelitian terus berkembang dalam hal perpindahan panas, yaitu dengan menggunakan media berpori. Hadirnya sistem pendingin media berpori diarapkan mampu untuk mengganti maka peran fin dan radiator yang lebih mudah perawatan dan mampu mentransfer panas dengan baik. Dalam hal ini penelitian dibantu oleh simulasi untuk melihat distribusi temperatur yang terjadi pada media berpori dengan variasi 10\%, 15\%, 20\% 25\%, 30\% Hasil penelitian dengan menggunakan simulasi menunjukkan bahwa semakin tinggi nilai porositas media berpori, maka nilai distribusi temperatur juga lebih besar. kemudian semakin tinggi nilai porositas maka nilai (h) koefisien perpindahan panas akan rendah.
\end{abstract}

Kata kunci : Porositas, Perpindahan panas, Temperatur

\section{Abstract}

The internal combustion engine is a fairly old machine and currently has many alternative energy which apparently has not been able to shift the role of the internal combustion engine, for the cooling system in the internal combustion engine greatly affect the performance and if not handled properly will cause something fatal, ie when the engine is too hot it can cause overheating and the machine cannot work anymore. For Cooling system has been using fin and radiator. Research continues to grow in terms of heat transfer, is by using porous media. Presence of porous media cooling system is expected to replace the role of fin and radiator easier maintenance and able to transfer heat well. In this case the research is assisted by simulation to see the temperature distribution that occurs in porous media with variation of $10 \%, 15 \%, 20 \% 25 \%, 30 \%$ The result of research by using simulation shows that the porosity value of porous media, the temperature distribution value also greater than. Then the higher the porosity value the value (h) the heat transfer coefficient will be low.

Keywords: Heat Transport, Porosity, Temperature

\section{PENDAHULUAN}

IImu pengetahuan dan teknologi terus berkembang dalam memberikan solusi untuk masalah sistem pendingin yang kerap timbul dari panas yang dihasilkan oleh mesin dan bagaimana cara memperbaiki fungsi pendinginan mesin. sebuah studi eksperimental tentang pengaruh

Correspondence address:

Ahmad Hamim Su'udy

Email : h4.mim.99@gmail.com

Alamat : Program Magister Teknik Mesin, Fakultas Teknik Universitas Brawijaya, Malang, Indonesia alur permukaan sirip pada sistem pendinginan mesin kendaraan bermotor, yang menyebutkan penggunaan bentuk sirip ke arah aliran fluida akan mempercepat pelepasan panas ke lingkungan [1].

Penelitian perpindahan panas juga berkembang dalam menyelidiki dinamika fluks panas dan konduktivitas termal yang terjadi selama kondensasi dengan metode eksperimen [2] kemudian dilanjutkan disimulasikan tentang media berpori untuk mengamati efek porositas media berpori melalui campuran cairan panas dan fluida dingin. Hasil penelitian ini menjelaskan bahwa porositas sangat berpengaruh terhadap 
perpindahan panas yang terjadi pada media berpori [3]. Selanjutnya diamati bahwa perpindahan panas dengan konveksi alami fluida viskositas bervariasi dalam medium berpori mengakibatkan kondisi porositas tinggi sehingga nilai Prandtl sebanding dengan nilai Nusselt, yang menyebabkan nilai alir meningkat juga [4].

Mengacu pada data paparan diatas banyak metode atau cara untuk memperbaiki fungsi pendinginan engine, dimana peneliti tertarik untuk melakukan penelitian tentang variasi porositas porous media yang disimulasikan pada sistem pendinginan bahan bakar motor.

Maka tujuan dari penelitian ini adalah untuk mendapatkan distribusi temperatur yang terjadi pada sistem pendingin bahan bakar motor dengan menggunakan media berpori. Hipotesis dapat ditarik dari tinjauan pustaka bahwa semakin besar persentase porositas, distribusi perpindahan panas pada media berpori meningkat dan laju perpindahan panas semakin lambat, maka semakin besar nilai konduktivitas termal efektif, distribusi perpindahan panas pada Media berpori berkurang, semakin cepat laju perpindahan panas.

\section{METODOLOGI PENELITIAN}

Penelitian ini dilakukan secara numerik dengan menggunakan Perangkat Lunak FEA, sehingga dapat diketahui pengaruh penggunaan model poros media pada sistem pendingin mesin pembakaran dalam. Selain itu, studi literatur tentang konduksi dan perpindahan panas konveksi juga dilakukan. Porous media adalah media berpori, di mana bahan terstruktur di dalamnya mengandung atau berisi ruang kosong yang disebut pori-pori dan dikelilingi oleh matriks padat atau semi-padat. Kemudian untuk rumus yang digunakan untuk porositas

$$
\varepsilon=\frac{\text { volume of pores }}{\text { Total material volume }} \times 100 \%
$$

Efektivitas efektifitas termal yang terjadi pada media berpori dapat menggunakan $K$ efektif (K_eff)

$$
\begin{aligned}
& K_{e f f}=\left[\left(1-\varepsilon^{2 / 3}\right)+\left\{\varepsilon^{2 / 3} /\left[\left(1-\varepsilon^{1 / 3}\right)+\varepsilon^{1 / 3}(k p / k a)\right]\right\}\right] \\
& k p
\end{aligned}
$$

Nilai (h) Pencarian dari koefisien perpindahan panas kemudian digunakan

$\mathrm{h}=\mathrm{Nu} \frac{K_{\text {eff }}}{\mathrm{D}}$
Sebelumnya kami mencari tentang Nusselt Number (Nu)

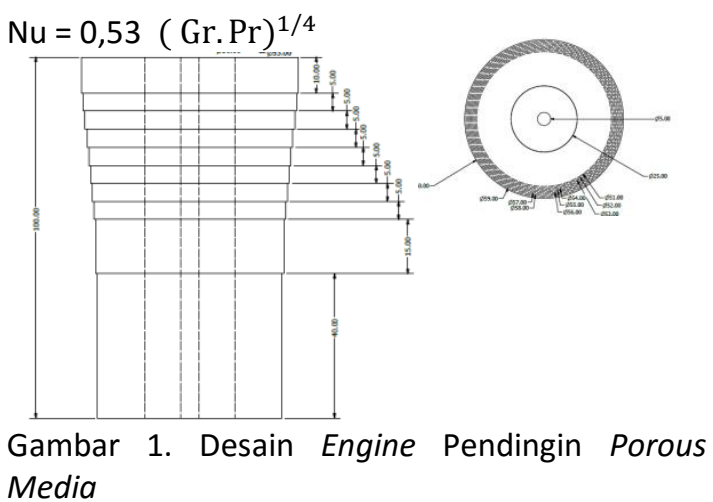

\section{HASIL DAN PEMBAHASAN}

Hasil data yang telah diperoleh dari hasil penelitian simulasi akan menggambarkan gradien temperatur dan nilai tabel distribusi temperatur pada media berpori.

Tabel 1. Data gradien suhu berpori Media simulasi

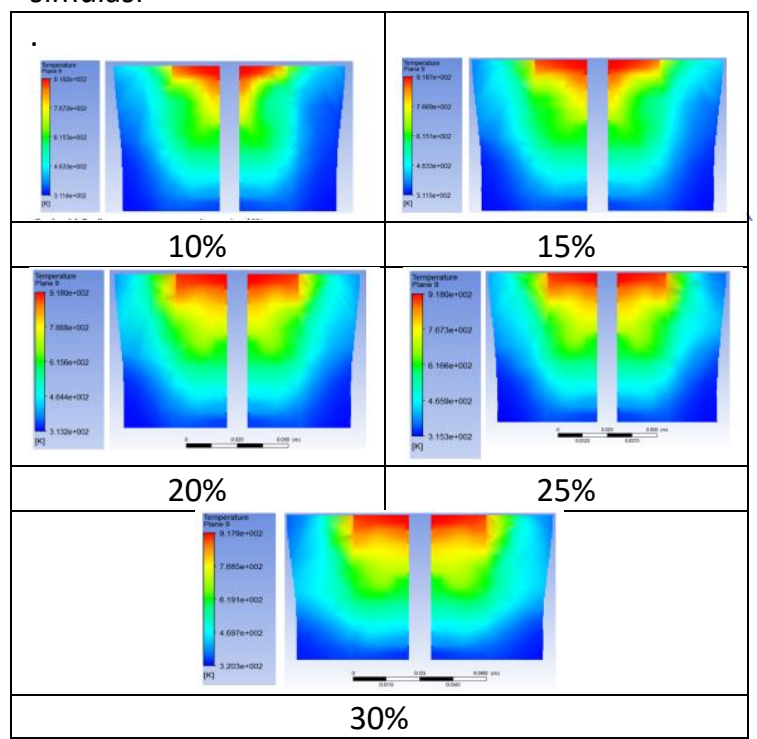

Koefisien perpindahan panas merupakan salah satu parameter yang digunakan dalam melihat distribusi temperatur yang terjadi pada perpindahan panas. Nilai (h) berhubungan erat dengan $\mathrm{K}$ efektif dan nilai $\mathrm{Nu}$.

Contoh perhitungan nilai koefisien perpindahan panas $\mathrm{h}$ pada kolom Y1 Porositas $10 \%$.

$$
\begin{aligned}
& \begin{array}{l}
\mathrm{Nu}_{\mathrm{y} 1 \mathrm{a}}=0,53(\mathrm{Gr} . \mathrm{Pr})^{1 / 4} \\
\quad=0,53(9,536 \mathrm{E}+02)^{1 / 4}=2,95 \\
K_{\text {eff }} \quad=\left[\left(1-0,1^{2 / 3}\right)+\left\{0,1^{2 / 3} /\left[\left(1-0,1^{1 / 3}\right)+0,1^{1 / 3}\right.\right.\right. \\
(220 / 0,024)]\}] 220=157,81 \mathrm{~W} / \mathrm{m} .{ }^{\circ} \mathrm{C}
\end{array}
\end{aligned}
$$




$$
\begin{aligned}
>\mathrm{h}_{\mathrm{y} 1 \mathrm{a}} & =\mathrm{Nu} \frac{K_{e f f}}{\mathrm{D}}= \\
2,95 \times & (157,81 / 0,000083) \\
& =5,578 \mathrm{E}+04
\end{aligned}
$$

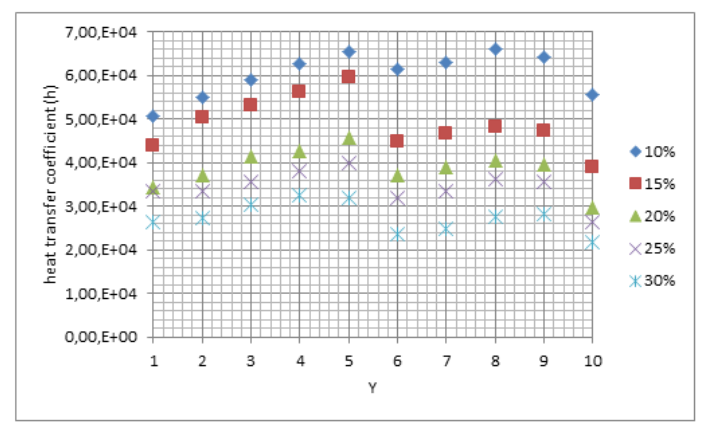

Gambar 2. Grafik Koefisien nilai perpindahan panas (h) pada Kolom A

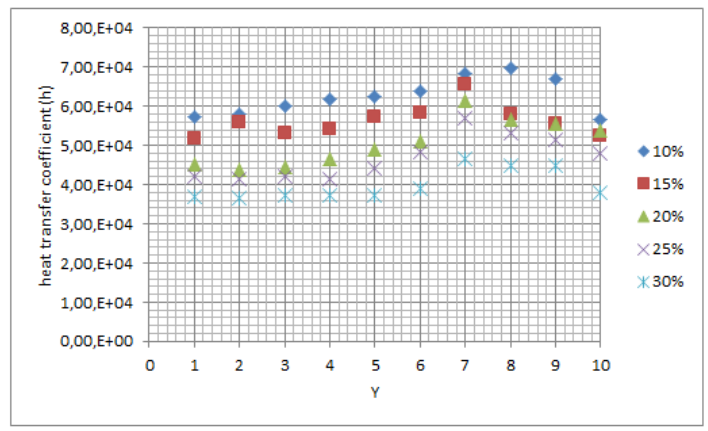

Gambar 3. Grafik Koefisien nilai perpindahan panas (h) pada Kolom B

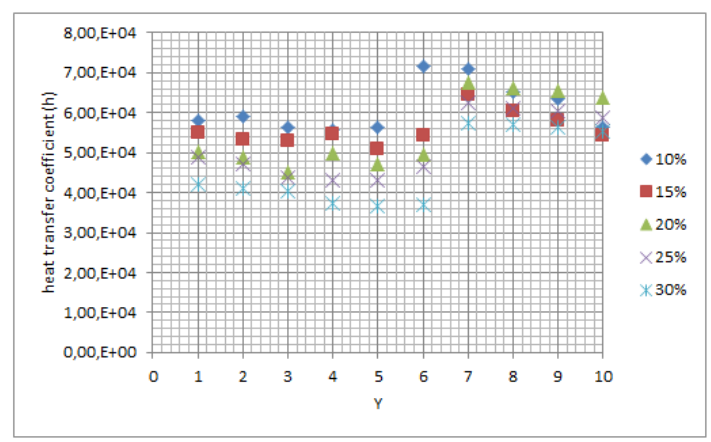

Gambar 4. Grafik Koefisien nilai perpindahan panas (h) pada Kolom C

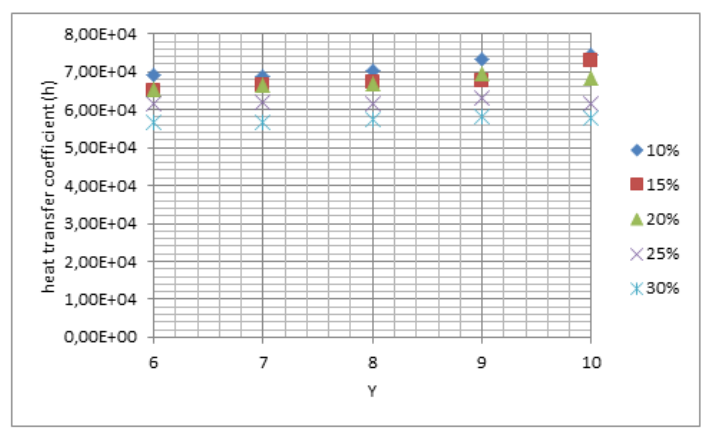

Gambar 5. Grafik Koefisien nilai perpindahan panas (h) pada Kolom D

Gambar grafis koefisien perpindahan panas di atas bila dilihat dari sudut pandang $\mathrm{A}$ atau Gambar 1. Pada porositas 10\% memiliki nilai $\mathrm{h}$ tertinggi dan nilai koefisien perpindahan panas juga diikuti oleh perubahan nilai porositas, dimana nilai koefisien perpindahan panas paling rendah jika dipahat dari kolom monitor A hadir pada Porositas 30\%. Selanjutnya pada Gambar 3, Gambar 3, dan Gambar 4. tunjukkan hal yang sama

\section{KESIMPULAN}

Salah satu penyebab yang mempengaruhi nilai konduktivitas termal efektif, apabila nilai porositas besar maka nilai $\mathrm{K}$ efektif kecil. Sehingga dapat disimpulkan bahwa semakin besar porositas nilai koefisien perpindahan panas akan semakin rendah.

\section{UCAPAN TERIMA KASIH}

Terimakasih kepada semua pihak yang telah membantu dalam menyelesaikan penelitian ini, terutama kepda pembimbing penelitian Bpk. Dr. Eng. Eko Siswanto,.S.T., M.T dan Prof. Dr. Ir. Rudy Soenoko, M.Eng.Sc. ibu dan bapak yang selalu memberikan semangat serta Safitri aulia rahma yang selalu mendampingi dalam menyelesaikan tugas tugas ini.sekali lagi terimakasih.

\section{DAFTAR PUSTAKA}

[1]. Samsudin Anis, Dkk. 2009. Studi Eksperimen Pengaruh Alur Permukaan Sirip pada Sistem Pendingin Mesin Kendaraan Bermotor. Jurnal Kompetensi Teknik. Unnes.

[2]. Siswanto Eko, 2013. Fluks Termal dalam Porous Media saat Mengkondensasi Uap. Jurnal Rekayasa Mesin Universitas Brawijaya. 
[3]. Y wang. 2015. Influence of the particle diameter and porosity of packed porous media on the mixing of hot and cold fluids in a T-junction. International Journal of Heat and Mass Transfer 84 (2015) 680-690.

[4]. Horng Wen Wu.2016. Heat transfer with natural convection of varying viscosity fluids inside porous media between vertically eccentric annuli.International Journal of Heat and Mass Transfer 94 (2016) 145-155" 